Article

\title{
The Whole Lifecycle Management Efficiency of the Public Sector in PPP Infrastructure Projects
}

\author{
Nannan Wang ${ }^{1, *}$, Minxun $\mathrm{Ma}^{2}$ and Yunfei Liu ${ }^{2}$ \\ 1 School of Maritime Economics and Management, Dalian Maritime University, No.1 Linghairoad, \\ Dalian 116026, China \\ 2 School of Management, Shandong University, No. 27 Shan Da Nan Road, Jinan 250100, China \\ * Correspondence: wangnannan@dlmu.edu.cn
}

Received: 29 February 2020; Accepted: 6 April 2020; Published: 10 April 2020

\begin{abstract}
The management role of the public sector in public-private partnership PPP infrastructure projects has been extensively expanded to the whole lifecycle rather than in the traditional infrastructure projects. The performance of the public sector in a PPP is the key for the PPP to achieve sustainability; however, there is a lack of research on the whole lifecycle management efficiency of the public sector in a PPP. This research aims to examine the governance role of the public sector in PPP projects, and therefore evaluate their whole lifecycle management efficiency. An evaluation framework is developed through the lens of governmentality to evaluate the performance of the public sector. Multiple case studies on PPP infrastructure projects in China have identified loopholes during the whole lifecycle of a PPP at the local governmental level. On the basis of the findings of case studies, a conceptual model is proposed to demonstrate ways for the public sector to improve efficiency through integrated governance of PPP projects. The research findings benefit both the central government in terms of evaluation and decision making and the local government by improving their efficiency in PPP infrastructure projects for the purpose of achieving sustainability. According to the findings, policy strategies are provided for the central government on how to further regulate the PPP market and address the loopholes, including further standardizing regulations and instruction, providing unified quantitative calculation or measurement tools, training, and education for the public sector to integrate whole lifecycle project management, and quality control of consultancy for the PPP infrastructure projects.
\end{abstract}

Keywords: public-private partnership; public sector; management efficiency; infrastructure; whole lifecycle

\section{Introduction}

As an innovative public procurement approach, public-private partnership (PPP) is an arrangement of collaboration between public and private sectors equipped with cooperation models for the purpose of formulating policies, providing infrastructure and public services for long-term benefits [1]. Through collaboration, the private sector provides public services according to the output specification of the public sector, where the two sectors can better complement each other's advantages, share risks and resources during the whole lifecycle of the project. Since the initiation of PPP in the UK, it has become an increasingly popular procurement approach to deliver public projects across countries all over the world [2].

In comparison to traditional procurement mechanisms, PPP has proven abilities to ease public financial burden, minimize whole life costs, improve risk management and infrastructure service, as well as increase transparency and accountability [3,4] through sustainable partnerships. A PPP infrastructure project has a more complex structure due to its long-term contract period and partnership 
relationship between the public and the private sector [5]. As one of the aims of PPP is to transform the function of government from an implementer to governor, the local government, referred to as the public sector in the PPP contract, is required to play a governance role [6] during the whole life of the asset. The efficiency of a PPP infrastructure project is largely dependent on the whole lifecycle management efficiency of the public sector, which is reflected in supervising, delegating, collaborating, negotiating with, and guiding the private sector to deliver the best value for money during the whole lifecycle of the project.

Governments in developing countries commonly face more difficulties managing obligations under a PPP project, due to the lack of cognition, finance constraint, and inherent bureaucracy [7]. China is the largest developing country, and one of the largest PPP markets in the world. In the past two decades, with rapid economic development and urbanization in China, a rapidly growing number of infrastructure projects have been initiated by PPP [2], however, the development of PPP is still at an early stage in China [8]. The management skills and efficiency of the public sector became critical for the success of PPP projects. There are PPP projects that have failed due to unrealized value for money, financing failure, and earning reduction. The major reason for this failure was the low management efficiency of the public sector and the lack of whole life performance assessment tools, which could cause serious delay, cost overrun, and a breakdown of the partnership with the private sector [9].

The public sector that adopts an integrated whole lifecycle management approach, plays a critical role in achieving sustainability $[10,11]$. In order to improve the success rate of PPP projects, management efficiency of the public sector must be improved and an evaluation tool for the central government to measure the management efficiency of the public sector during the whole lifecycle of PPP is urgently needed to help the central government identify loopholes in PPP implementation, formulate policy strategies to target problems, and guide the local authorities to achieve better results from their local PPP projects in practice. Nevertheless, previous studies on PPP evaluation have mostly focused on either the micro-level private sector performance review, project assessment, or the macro-level governance issues. There is a lack of research regarding the whole lifecycle management efficiency of the public sector at the project level from the whole lifecycle perspective of a PPP project. The concept of effective integrated whole lifecycle management of PPP requires further investigation. The measurement of the performance of the public sector needs the help of a systematic framework considering the key indicators during the whole lifecycle management of PPP.

Governmentality, also referred to as "mentalities of government", is concerned with how governors think about governing, with different rationalities [12]. Governmentality explains the ways of governing [13], and reflects the ways governing institutions interact with those that are governed [14]. It has been associated with the studies on the discussion of governance-related issues.

This research sheds a light on the development of an evaluation framework through a governmentality lens, hence examining the whole lifecycle management performance of the public sector in PPP infrastructure projects, and helping the central government adjust tactics to improve the management efficiency of the local governments. The research results contribute to the literature regarding management performance evaluation and the integrated sustainability-oriented whole lifecycle management of PPP. The research objectives include the following: (1) Identifying the key indicators of whole lifecycle management efficiency of the public sector and forming a framework to benefit the central government in evaluating the performance of the local governments, (2) examining the performance of the public sector in a PPP by multiple case studies to identify loopholes and provide appropriate policy support to the central government, and (3) exploring the ways the public sector achieves excellent management efficiency through the governance of a PPP project whole lifecycle and builds a concept model for the effective integrated whole lifecycle management of PPP.

The outline of this paper is as follows: Section 2 provides a literature review on PPP governance, management performance and the role of the public sector; Section 3 describes the methodology for data collection and analysis; the findings and discussions are presented in Sections 4 and 5 respectively, Section 6 presents the conclusions from the research. 


\section{Literature Review}

\subsection{Studies on Macro-Level PPP Governance}

Governance can be defined as the management of an entity at the highest level of organization, which includes the institutions, rules, and procedures of government [15]. On the macro level, a number of researchers have discussed the role of central government in governing a PPP. Wibowo et al. [16] identified 30 government-led critical success factors (CSFs) to evaluate government performance in PPP infrastructure projects, including sound legal environment, strong political support, effective contract management, reasonable risk allocation and sharing, and a clearly defined coordination mechanism. Liu et al. [17] used a vector error correction model to identify eight key performance indicators (KPIs) for the assessment of the macroeconomic environment of a PPP, and claimed that these KPIs were essential for central government to conduct a comprehensive ex-ante evaluation which was crucial to the success of a PPP project. The constitution of good governance of PPPs was explored in a research focus on PPP governance in a strategic version such as Wilson et al. [6].

\subsection{Studies on Micro-Level Project Performance}

The CSF of PPP projects is one of the main research interests of micro-level studies. The CSF model has become one of the most efficient approaches for ensuring the success of PPP projects [18]. Considering the significance of the early briefing stage of PPP, Tang et al. [19] discussed the CSFs for this stage, including risk identification, an effective and open communication environment, and a practical budget and programme. A study by [9] endeavored to select an appropriate private sector under the best value for the money criterion through a best value source selection (BVSS) approach. Furthermore, researchers have explored CSFs during other stages of the lifecycle of PPP, for example, the feasibility stage [20], design stage [21], tendering process [22], and concession period [23].

The literature on CSF provides a pool of knowledge for researchers to use to formulate a project performance assessment framework. A study based on a literature review of CSF-related studies established several KPI systems as the key stakeholders in a PPP, including the public sector, the private sector and users, and emphasized the different roles of various stakeholders [24]. Similarly, based on a literature review of CSF, Yuan et al. [25] developed a KPI framework, but aimed to assess the overall performance of PPP projects rather than individual stakeholders.

\subsection{The Role of Public Sector in PPP}

The management capacity and the characteristics of the public sector play critical roles in the success of a PPP project and the partnership between the public and private sectors [26]. However, the current relationship between the public and private sectors in the construction industry in China is somehow unequal [10], which is adverse to the establishment of a partnership between the two parties and can cause project failure. Because the government holds strong power on authorization and resources in China, the private sector usually needs to spend much time and money to keep a good relationship with the public sector in order to obtain resources or expedite the government approval process [27].

Through the whole lifecycle of the project, the roles and responsibilities of the public sector vary in different stages of the PPP project. The appraisal and selection of appropriate PPP projects is the first challenge encountered by the public sector in PPP project. Researchers have suggested that the key tasks for the public sector to complete in managing PPP projects are the following: (1) feasibility and profitability study [24]; (2) output specification; (3) sustainable development analysis [28]; (4) risk management $[2,3,23,24,29]$; and (5) value for money analysis $[2,24,25,28]$. In order to ensure the smooth process of a PPP project, all these tasks need the efficient cooperation and management from the public sector [28]. The integration of the traditionally segmented stages by PPP advantage the government by achieving sustainable long-term objectives and value for money [2]. 
The procurement stage of a PPP project includes a bidding process and contract finalizing [22]. Creating a transparent and competitive environment at this stage is crucial to the success of a PPP project $[16,24,28,30]$. The public sector is responsible for the success of a competitive bidding in terms of clear requirement specification, a good tender list, and a competitive tension throughout the lifecycle of the project [22]. Given the importance of a strong private consortium, the public sector should also assist the private consortium to strengthen the capacity to complete private financing during this stage $[2,23]$.

The implementation of PPP is the longest and most important stage, during which the management capacity of the public sector plays a critical role. Taking long-term benefits into consideration, the public sector should guide the private sector through a whole life cost appraisal and whole life design optimization. During construction, the public sector should supervise the performance of the private sector for cost, quality, time, health and safety, environment, conflict, prominent techniques, and skills $[2,24,25,31,32]$.

At the operation stage, the conduct of payment mechanism plays an important role to ensure the delivery of the best value for money $[28,30,33,34]$. Therefore, the design and monitoring of the payment mechanism is the main responsibility of the public sectors that are managing PPP projects [35].

\subsection{Governmentality of Governors}

The main themes in governmentality theory include power, knowledge, and rationality [36-38]. Power is effective when executed subtly in organizational hierarchies with the input of knowledge [36], and those being governed should be framed in enclosure in order to be assigned responsibilities, and evaluated for performance [39]. Enclosure specifies the boundary of the organization and enables the institutionalization, such as calculation, rules, and regulations of governmentality $[40,41]$. Rationality indicates the method of reasoning, calculating, and responding to a systematic problem, which requires utilizing certain bodies of knowledge and expertise [42]. Power is diffused and rational and can be most effective when subtly executed in organizational hierarchies through the form and use of knowledge, with the help of control [36]. Therefore, the study of governmentality must take into consideration the domain of rationality, technique, program, and identities of regimes of governments [42].

Governmentality can be applied at different levels of the analysis, such as the governance of state, organization, or family [13]. The introduction of governmentality theory into the organizational level can help to better understand the way governors think about governance and the way power functions by subtly influencing individuals to be complicit in their governance [43]. In this case, the governmentality theory can be used to examine the exercise of power through an organizational structure and the individual's role in the structure [44-46]. When applied in the analysis of the governance of organizations, the most commonly adopted analytical dimensions have included knowledge [46-48], instrument and techniques [46,49,50], process [51], and rationality [38,52]. For instance, Abdullah and Khadaroo [40] discussed the governmentality of a museum from institutions, processes, analyses, calculations, and tactics to understand the way a body of knowledge exerted power for subjectivation and objectivation of the institute. In a study concerning project governance, Müller, et al. [45] selected three aspects, namely, organizational values, process, and project wellbeing, which represented the preference of governors for managing projects, to measure governmentality.

Governmentality in PPP, as referred to in this research, reflects the mentality of the public sector on governing PPP projects, i.e., how the public sector employs private sector's professional knowledge of integrated project management, and use appropriate techniques and instruments, calculations, and evaluations to control the process to achieve the desired outcomes. 


\section{Methodology}

\subsection{The Identification of Indicators}

The indicators that relate to management efficiency of the public sector in PPP projects were identified through an in-depth literature review. The peer-reviewed international journal articles were selected from three key databases including Web of Science, Elsevier, and ASCE, by searching the title, keywords, and abstract that contained PPP/PFI//BOT/BOOT/, and CSF/management efficiency/governance public sector. The full-text of the articles was screened to filter for indicators that were related to the role of the public sector in PPP projects.

On the basis of the literature review, the indicators relating to the management efficiency of the public sector in PPP are identified, as shown in Table 1.

Table 1. Indicators relating to the public sector in public-private partnership (PPP) project whole lifecycle.

\begin{tabular}{ll}
\hline Indicators & Reference \\
\hline Appropriate risk management & {$[3,23,24,28,29,53-55]$} \\
Transparency & {$[16,23,24,28-30]$} \\
Effective technology transfer and innovation & {$[16,23,24,54,56]$} \\
Well-structured legal dispute resolution mechanism & {$[16,23,28,29,55]$} \\
Value for Money & {$[24,25,28,53]$} \\
Cost control & {$[31,32,35,56]$} \\
Service-driving pay mechanism & {$[28,33,34]$} \\
Better construction and service quality & {$[20,25,56,57]$} \\
Sustainability & {$[28,53,54,56]$} \\
Utilization of private skills & {$[4,54,56]$} \\
Service specification & {$[28,35,58]$} \\
Competitive dialogue & {$[16,22,23]$} \\
Whole life costing optimization & {$[4,24,25,53]$} \\
Private financing & {$[23]$} \\
Adherence to time & {$[32,59]$} \\
Long-term objective & {$[24,54]$} \\
Environment management & {$[9,17,24,60]$} \\
Professional cross-disciplinary cooperation & {$[2,28]$} \\
Effective tendering process control & {$[2,53]$} \\
Integrated project management & {$[61]$} \\
Profitability & {$[24,62]$} \\
Market testing & {$[2]$} \\
Leadership & {$[29]$} \\
Community engagement & {$[2,62]$} \\
Openness and constant communication & {$[62]$} \\
Strong government commitment and support & {$[55,62]$} \\
Service performance review & {$[2,4]$} \\
Clear division of roles and responsibilities & {$[29]$} \\
Relationship management & {$[4]$} \\
Contract management & {$[22,63]$} \\
Public accountability & {$[22,55]$} \\
Design for whole life & {$[4]$} \\
\hline & \\
&
\end{tabular}

\subsection{The Development of Analytical Framework}

The indicators identified through the literature review were, then, categorized using the following four dimensions of governmentality, to reflect the ways the public sectors governing PPP projects achieve the long-term goals of the government:

- Rationality means the state of having good sense and sound judgment in governing PPP projects, such as prioritization of organizational values, and realizing the values;

- Techniques represent instruments, technologies, calculation, and tactic used in governmentality; 
- Knowledge concerns the form and use of knowledge;

- Process emphasizes process compliance through control and monitoring.

On the basis of the classification, a framework for measuring the management efficiency of the public sector in PPP projects was developed in a systematically and hierarchical structure, as shown in Figure 1. The framework served as a tool to examine the management efficiency of the public sector in PPP project through a governmentality lens.

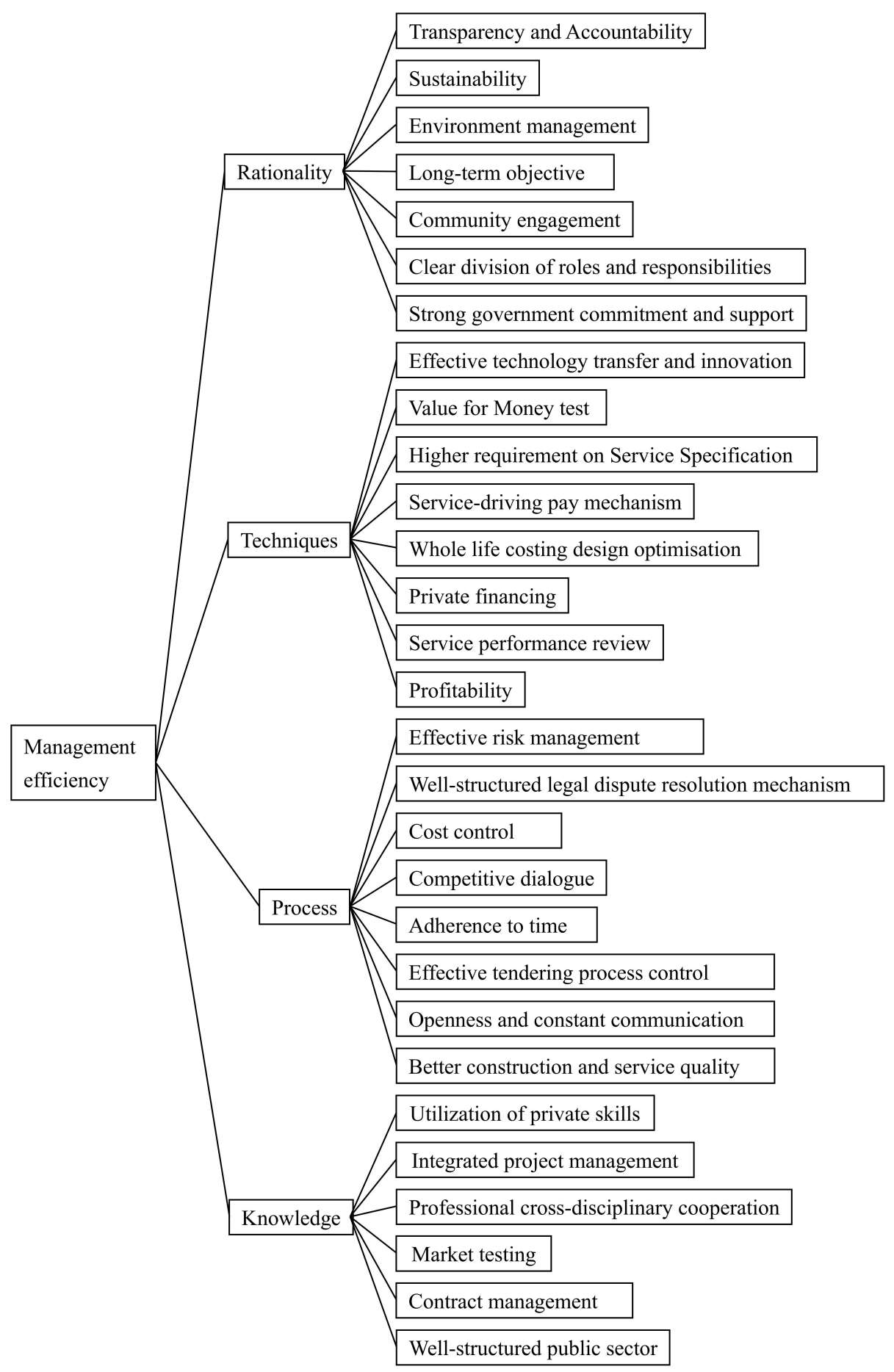

Figure 1. The evaluation framework of the PPP management efficiency of public sector. 


\subsection{Case Study Design}

The theoretical sampling approach was adopted with the aim of replicating or extending the existing theory [64]. Four purposeful PPP cases were selected from small to medium-sized cities in the less developed regions in China, where the PPP is most needed to mitigate the short-term fiscal difficulty of the local governments and develop the outdated municipal infrastructure, whilst the local governments are less experienced in managing PPP projects.

In order to improve the external validity of the case study method, a two-way strategy [65] was introduced in this case study. First, the research was conducted by a team of researchers, and second, the cases covered four different types of infrastructure projects. The basic information of the cases is listed in Table 2.

Table 2. The basic information of four case projects.

\begin{tabular}{|c|c|c|c|c|}
\hline & Case I & Case II & Case III & Case IV \\
\hline Project name & $\begin{array}{l}\text { A city transport } \\
\text { infrastructure PPP project }\end{array}$ & $\begin{array}{l}\text { B city Smart City } \\
\text { infrastructure } \\
\text { PPP project }\end{array}$ & $\begin{array}{l}\text { C city underground } \\
\text { utility tunnel PPP project }\end{array}$ & $\begin{array}{l}\text { D city central district } \\
\text { heating PPP project }\end{array}$ \\
\hline Local authority & $\begin{array}{l}\text { A city housing and } \\
\text { urban-rural } \\
\text { development bureau }\end{array}$ & $\begin{array}{l}\text { B city housing and } \\
\text { construction bureau }\end{array}$ & $\begin{array}{l}\mathrm{C} \text { city municipal public } \\
\text { utilities administration }\end{array}$ & D city council \\
\hline Type of construction & New build & New build & New build & Renovation \\
\hline Project scope & $\begin{array}{l}\text { Part of A city municipal } \\
\text { road, bridges and } \\
\text { landscaping infrastructure }\end{array}$ & $\begin{array}{l}\text { Smart city infrastructure } \\
\text { - smart city control center, } \\
\text { big data center, smart IT } \\
\text { system, public safety } \\
\text { video monitoring } \\
\text { network, smart lighting } \\
\text { system }\end{array}$ & $\begin{array}{l}\text { Five major municipal } \\
\text { underground } \\
\text { utility tunnels }\end{array}$ & $\begin{array}{l}\text { Part of D city district } \\
\text { heating system with the } \\
\text { application of clean } \\
\text { coal technology }\end{array}$ \\
\hline
\end{tabular}

(Source of data: Project contracts).

The case projects from different cities covered a variety of municipal PPP infrastructure projects, ranging from 495 to 14,532 million RMB. The whole lifecycles of the projects were between 23 and 28 years.

\subsection{Project Assessment and Comparison Study}

The analytical framework was used for the case projects to evaluate the management efficiency of the public sector involved in them. The triangulation was adopted for data validation purposes [66]. The project data were collected through document reviews and interview surveys with the permission of the clients. The documents for each project included project contract, feasibility report, project proposal, project evaluation report, overall project financial data, and partial operational data. For the information that could not be retrieved by document review, a further interview survey was carried out, where four project managers from the case projects were invited to provide extra information related to the assessment of the indicators. The experts were between 35 and 46 years of age and had over five years of working experiences. A five-point Likert scale, from 1 star, i.e., extremely poor performance (represented by ${ }^{*}$ ) to 5 stars, i.e., excellent performance (represented by ${ }^{* * * *}$ ) [2], was adopted to evaluate the performance of the public sector in each case project against each indicator in the form of consensus meetings. The experts reached the final evaluation results after three rounds of consensus. On the basis of the initial evaluation results, a cross-case comparison was conducted.

\section{Findings}

The evaluation results of the four case projects against the selected indicators after consensus are shown in Table 3. The case projects appear to have significant similarity on some indicators but diverge on some other indicators. 
Table 3. The management efficiency evaluation results of case projects.

\begin{tabular}{|c|c|c|c|c|c|}
\hline Dimensions & Indicators & Case I & Case II & Case III & Case IV \\
\hline \multirow[t]{7}{*}{ D1 Rationality } & R1 Transparency and accountability & $* * *$ & ***** & $* * * *$ & $* * * *$ \\
\hline & R2 Sustainability & * & $* * *$ & ** & $* * * *$ \\
\hline & R3 Environment management & $* * *$ & $* * *$ & ** & $* * * *$ \\
\hline & R4 Long-term objective & $* * * * *$ & $* * * * *$ & $* * * * *$ & $* * * * *$ \\
\hline & R5 Community engagement & $* * *$ & *** & $* * *$ & $* * * *$ \\
\hline & $\begin{array}{l}\text { R6 Clear division of roles } \\
\text { and responsibilities }\end{array}$ & $* * *$ & $* *$ & ** & $* * *$ \\
\hline & $\begin{array}{l}\text { R7 Strong government commitment } \\
\text { and support }\end{array}$ & $* * * *$ & $* * * *$ & $* * * *$ & $* * * *$ \\
\hline \multirow[t]{8}{*}{ D2 Techniques } & $\begin{array}{l}\text { T1 Effective technology transfer } \\
\text { and innovation }\end{array}$ & $* * *$ & $* * *$ & $* * *$ & $* * * * *$ \\
\hline & T2 Value for Money test & $* * * *$ & $* * * *$ & $* * *$ & $* * * *$ \\
\hline & $\begin{array}{l}\text { T3 Higher requirements on Service } \\
\text { Specification }\end{array}$ & * & $* * *$ & $* * *$ & $* * * *$ \\
\hline & T4 Service-driving pay mechanism & $* * * *$ & $* * * *$ & $* * *$ & $* * * *$ \\
\hline & $\begin{array}{l}\text { T5 Whole life costing design } \\
\text { optimization }\end{array}$ & $* * * *$ & $* * * * *$ & $* * *$ & $* * * *$ \\
\hline & T6 Private financing & $* * * *$ & $* * * * * *$ & $* * * *$ & $* * * * *$ \\
\hline & T7 Service performance review & $* * * * *$ & $* * * *$ & $* * *$ & $* * * * *$ \\
\hline & T8 Profitability & $* * *$ & * & $* * *$ & $* * *$ \\
\hline \multirow{8}{*}{$\begin{array}{l}\text { D3 } \\
\text { Process }\end{array}$} & P1 Effective risk management & $* * * * *$ & $* * * * *$ & $* * * * *$ & $* * * * *$ \\
\hline & $\begin{array}{l}\text { P2 Well-structured legal dispute } \\
\text { resolution mechanism }\end{array}$ & * & * & * & * \\
\hline & P3 Cost control & * & * & * & * \\
\hline & P4 Competitive dialogue & $* * * *$ & $* * * *$ & $* * * *$ & $* * * * *$ \\
\hline & P5 Adherence to time & * & * & * & ** \\
\hline & P6 Effective tendering process control. & $* * * *$ & $* * * *$ & $* * * *$ & $* * * *$ \\
\hline & $\begin{array}{l}\text { P7 Openness and constant } \\
\text { communication }\end{array}$ & ** & ** & ** & $* * *$ \\
\hline & $\begin{array}{l}\text { P8 Better construction and service } \\
\text { quality }\end{array}$ & $* * *$ & $* * * *$ & $* * * * *$ & $* * * * *$ \\
\hline \multirow{6}{*}{$\begin{array}{l}\text { D4 } \\
\text { Knowledge }\end{array}$} & K1 Utilization of private skills & $* * *$ & $* * *$ & ** & $* * * *$ \\
\hline & K2 Integrated project management & ** & ** & ** & $* * *$ \\
\hline & $\begin{array}{l}\text { K3 Professional cross-disciplinary } \\
\text { cooperation }\end{array}$ & * & * & * & * \\
\hline & K4 Market testing & ** & ** & ** & $* * *$ \\
\hline & K5 Contract management & * & * & * & * \\
\hline & K6 Well-structured public sector & $* * *$ & $* * *$ & $* * *$ & $* * * *$ \\
\hline
\end{tabular}

Note: ${ }^{*}$, extremely poor performance; ${ }^{* *}$, poor performance; ${ }^{* * *}$, satisfactory performance; ${ }^{* * * *}$, good performance; and $* * * *$, excellent performance.

The case projects generally show excellent performance on R4, long-term objectives; T6, private financing; and D3, effective risk management; but, poor performance on R6, clear division of roles and responsibilities; P2, well-structured legal dispute resolution mechanism; P3, cost control; $\mathrm{K} 3$, professional cross-disciplinary cooperation; $\mathrm{K} 5$, contract management; and $\mathrm{P} 5$, adherence to time. The main divergence of performance lies on R2, sustainability; T3, higher requirement on service specification; T1, effective technology transfer and innovation; and T8, profitability. In comparison with other projects, Case VI had a better overall performance, with an average score of 3.6 stars and, in contrast, Case III had the lowest average score of 2.8 stars.

\subsection{Rationality}

The public sector for the case projects showed high management efficiency on R4, long-term objectives; R7, strong government commitment and support; and R5, community engagement. All the case projects set up the long-term objectives in the key project documents, such as project proposal, feasibility report, and contract. The public sector also linked the project outcomes with the long-term urban development plans of the local governments.

As required by the central government, the key financial data of the PPP projects were all publicized in the PPP database of the national PPP Centre in China, which is managed by the Department of Finance of PRC and open to the public. In order to increase the transparency of the PPP projects, the public sector of the four case projects established a project monitoring mechanism, including 
pre-project monitoring and process monitoring. Cases II and III adopted additional post-project monitoring for the hand-back period, which were not found in other case projects. Being a clean coal central district heating project taking sustainability as the key objective, Case IV added a sustainability assessment monitoring system and user satisfaction survey to test the environmental effect and carbon reduction efficiency during the operational stage. The results of those monitoring systems are accessible to the general public through an official website. The feedback from the community was taken into consideration in the problem-solving strategies of the public sector for managing the private sector.

The public sector in the case projects was generally supportive of the private sector in the projects, especially during the preparation stage. Before construction commenced, the public sector of the case projects coordinated with relevant administrative authorities to promote the project examination and the approval process. This was a great help to the private sector, as the approval process can be "tedious and time consuming".

The first three cases generally performed unsatisfactorily on environmental management and sustainability. In Case I, sustainability was not included in the project objectives, or the contract obligation. Cases II and III mentioned sustainability only in their project objectives, whereas Case IV embedded sustainability and environmental management into the project objectives, contract obligations, and project assessment.

The public sector all specified principle authorization arrangement in the four projects. The division of roles and responsibilities was found in the project contracts, but with different degrees of details.

\subsection{Techniques}

The case projects performed relatively better on this dimension, as the indicators $\mathrm{T} 6$, private financing; T2, value for money test; and T7, service performance review, were all above four stars, indicating good implementation of these techniques by the public sector. Technical reviews were carried out by the public sector on the financing means and consortium to ensure the stability of private finance. The financial structures were clarified in most cases, except for Case III that lacked a graphical description.

R6, clear division of roles and responsibilities, gained the lowest average score of 2.5 stars. Significant diversity appeared for T3, higher requirement on service specification, whereas Case I only gained one star and Case IV gained four stars. There was no detailed service specification in Case I, as in the other three cases. Case IV included very detailed service specification and also quantified technical measurements in the project contract. The whole life costing design optimization was adopted in the key decision making during the tendering and design stage. However, the appraisal was not always based on quantitative analysis, for example, there was no detailed breakdown of the whole life cost budget available for Case III.

The public sector, in Cases I and II, considered the profitability issue during the operational stage of the projects in brief, but failed to conduct quantitative calculations. Meanwhile, Cases III and IV provided a detailed forecast and calculation on project profitability. As commended by the experts, "the lack of detailed guidance" caused inconsistency in the behaviors of the public sector across the projects.

\subsection{Process}

The performances of the public sector on this dimension were rather synchronized, being strong on P1, effective risk management and P8, better construction and service quality. The four projects developed very detailed risk allocation strategies and risk management strategies covering the whole lifecycle of the projects. The improvement of construction and service quality were also written in the project contracts as one of the project objectives. In addition, it was taken into consideration in the project assessments of Cases II, III, and IV.

Despite the good performance on the former indicators, the public sector was extremely inefficient on P2, well-structured legal dispute resolution mechanism; P3, cost control; P5, adherence to time; 
and P7, openness and constant communication, as there was no detailed legal dispute resolution mechanism, cost and time restrictions (except for construction completion dates), and communication plans found in the project documents. According to the interviewees, the public sector seemed to believe that the private sector should be mostly "responsible for the time and cost control", which were largely related to the micro level of risks.

\subsection{Knowledge}

The public sector for the four case projects showed extremely low efficiency on this dimension, as the overall average score was around two stars. The local governments all purposefully selected project management teams representing the public sector to manage the PPP projects. Nonetheless, there was only one government officer in Case IV who had certain previous practical experience in PPP. In the other three cases, the public sector employed private consultancy services at the concept stage of the projects to help form the contracts and project regulations. Nevertheless, the project contract for Case III was, to some extent, incomplete, as the detailed project financing protocol and project company articles of association were missing. The detailed arrangements for contract monitoring and change protocol were also lacking for Case III.

Although the public sector included K1, utilization of private skills, as one of the project objectives, particular strategies were generally lacking in the case projects. There were no evidences that showed that the projects encouraged and conducted cooperation between the private professionals of different disciplines during the design and construction stages, when the cross-sector knowledge exchange has been shown to be most needed to reduce whole life costs [4]. In Case III, the public sector even provided an architecture design of the project, leaving only the financing, construction, and operation services to the private sector. In this case, the private sector only contributed limited creativity and innovation skills, as they were not involved in some challenging skilled tasks, such as design for whole life and plan for maintainability.

$\mathrm{K} 2$, integrated project management, was adopted in the value for the money test of the case projects, with very little mention elsewhere. Moreover, $\mathrm{K} 4$, market testing in the case projects remained mostly a high-level analysis, where prudent forecasting and calculations were absent.

\section{Discussions}

The management efficiency of the public sector in PPP was examined from an innovative angle considering the whole lifecycle of the PPP projects. The results benefit both central and local governments. On the one hand, the local government can conduct a self-assessment against each indicator to identify weaknesses in management and improve their management skills. On the other hand, the central government can evaluate the performance of the local governments by using the indicators within the framework developed in this research. The feedback on evaluation can further help the central government identify loopholes and adjust relative strategies accordingly to guide the local governments to better manage PPP projects.

\subsection{The Comparison of Case Projects}

The case study showed that the local governments for PPP projects could easily lose their focus in the long-term contractual relationship due to the distinct features and complex structure of the PPP whole lifecycle. The comparison of the average scores on each dimension of governmentality (see Figure 2) shows an uneven distribution across the case projects. The public sector for the four case projects was generally good at techniques ( 3.6 stars) and rationality ( 3.5 stars) dimensions, whereas it was relatively poor on process ( 2.9 stars) and knowledge (2.1 stars). 


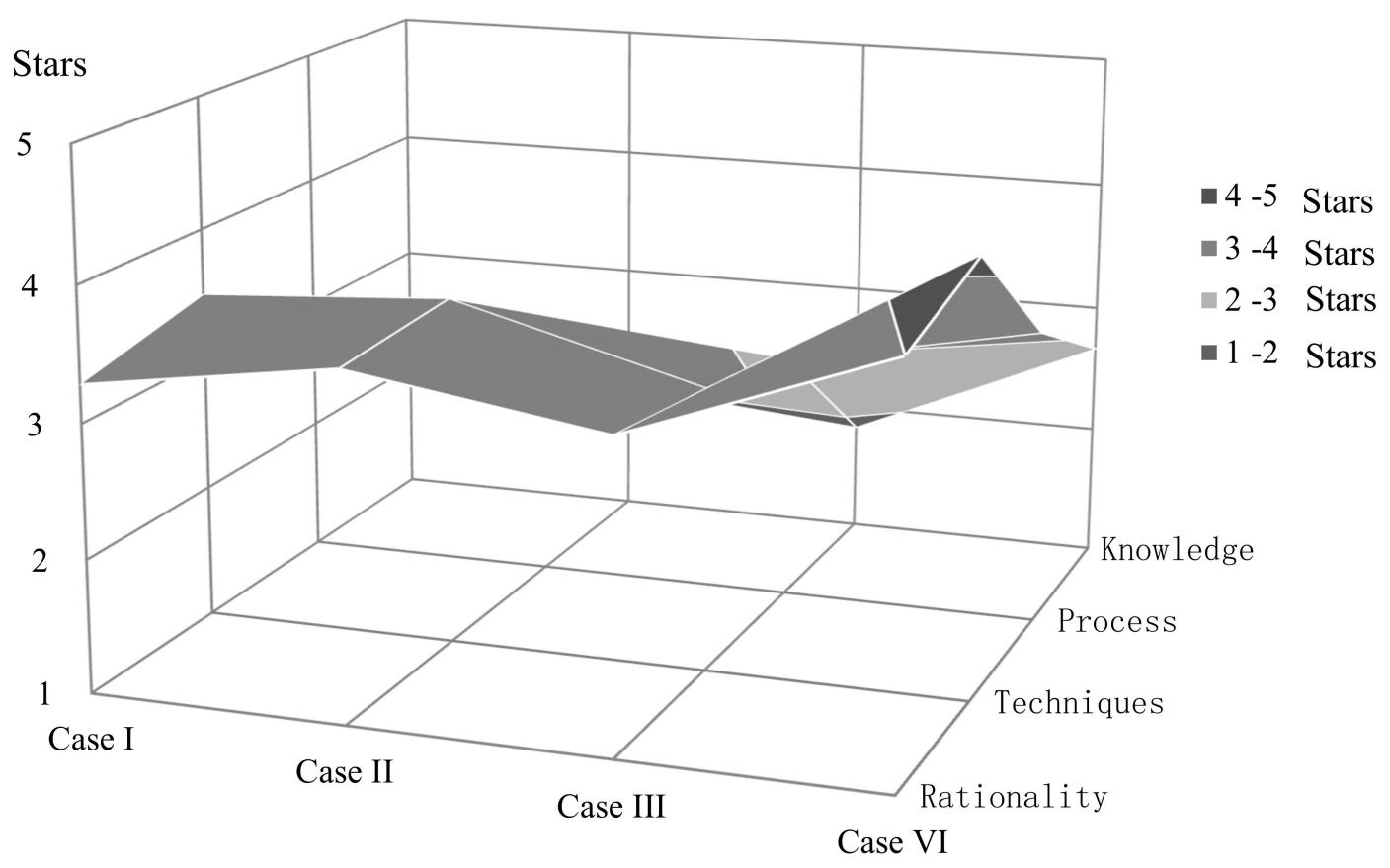

Figure 2. Management efficiency of case projects on four dimensions.

The public sector for the case projects generally had a good sense of governing, and appropriate use of techniques to govern the projects, whereas the control of process, nevertheless, seemed inadequate for case projects. Although the micro-level project risks have been transferred to the private sector in PPP, it is still the client's responsibility to monitor the overall performance of the project on cost, time, and quality in order to prohibit project failure in any construction projects [32]. The knowledge power nexus suggests that the form of knowledge is a key component of governance [12,37]. The unfortunate poor performance of the public sector for the case projects on knowledge indicated low efficiency in the form and use of knowledge during the project process.

In terms of individual indicators, the comparison showed great similarities across the projects on a number of indicators. In general, the public sector behaved well on R4, long-term objectives; P1, effective risk management; T6, private financing; and R5, community engagement; but with significant room for improvement on P2, well-structured legal dispute resolution mechanism; P3, cost control; K3, professional cross-disciplinary cooperation; and $\mathrm{K} 5$, contract management. It was discovered that, for the indicators that gained high scores, there were always official regulations or guidance available, issued by the central government as instructions to the local governments. However, for those less regulated indicators, the public sector in PPP had to make decisions on whether and how to conduct such practices.

Another reason for the unsatisfactory performance of the public sector on some indicators is the lack of experience. As commented by interviewees, the local governments in the four cities were "most familiar with traditional procurement methods of infrastructure projects", where the design, construction, maintenance, and operation were distinctly separated stages and the initial capital was financed by the public finance. Therefore, the public sector did not need to manage the whole lifecycle of the infrastructure from design, construction, to maintenance and operation. The public sector, as the initiator, mostly manages the construction contract, whilst the other stages were "supervised by other governmental departments". However, under the arrangement of PPP, the project contract covers the whole lifecycle of an infrastructure project, which requires the public sector to link the former segregated stages and govern the whole lifecycle of the project in an integrated manner and consider the long-term benefits of the project. In the design of the project contract, the public sector performed as "a coordinator between the local Development and Reform Commission and the consultancy", 
who was the main player in contract design. In practice, however, the public sector lacked a complete understanding of the whole contract and felt it was "difficult to foresee the future potential legal disputes" due to the complexity of PPP contractual relationships. The consultancy service had not developed to cover the whole lifecycle of PPP project but was only available at the project initiation stage, the public sector "had difficulty in managing a signed contract in a coherent way during the long-term implementation stage of contract". In addition, the performance review by the central governmental department to supervise the public sector did "not include the contract management as one assessment criterion, which also affects the public sector to focus on priorities in contract management."

Despite the similarities, the management efficiencies of the public sector for the four case studies appeared very differently on R2, sustainability; T1, effective technology transfer and innovation; and T3, higher requirement on service specification. Since there were no clear requirement and regulations given by the central government on these indicators, each public sector developed rather different approaches. Some public sectors, such as in Case IV, prioritized formal documents to clarify the requirements and standards under principal objectives, whereas other public sectors, for example Case III, only included the high-level requirements in the objectives and "relied on tacit understanding with the private sector to form the cooperative relationships".

The potential reasons for the inconsistency between the case projects could be that the public sectors were not aware of the importance of these items, or they did not know the appropriate way to deliver. Another reason, as suggested by the interviewee from Case III, was "the fear of the public sector on the unforeseen future of the partnership" and "would like to keep a dominating control position and flexibility" in the relationship. Therefore, the public sector preferred to leave some items unclearly explained in formal documents, especially those non-standardized measures, so that they could keep flexibility in decision making.

Furthermore, the third party, i.e., the consultancy was also found to be an influential factor to the management efficiency of the public sector in the case projects. For those less experienced local governments, the private consultancy was an important source to gain management skills and experience on PPP projects. However, the quality of the consultancy services appeared uneven, which significantly affected their management efficiency in PPP. For instance, the high-level standard contract for PPP issued by the central government provided risk allocation principles and guidance. Therefore, the risk allocation and management strategies adopted by the public sector of the four projects were counterpart and managed well. Nevertheless, the lack of guidance on contract monitoring and change management caused a very low efficiency of the public sector on contract management.

\subsection{The Way Forward}

The process of achieving excellent management efficiency during the whole lifecycle of a PPP project can be illustrated by a conceptual model (see Figure 3), regarding the governance role of the public sector in a PPP project.

The role of the public sector in governing a PPP project includes four core dimensions, as in the center of the model. The governance is initiated by the perception of the sense of governing, followed by the utilization of techniques to control the project process, and then a learning procedure for the use and form of knowledge through the integrated project management process during the implementation of a PPP. During process control, the public sector gains management capabilities through the practice of monitoring and controlling with the help of the instructions from the central government. Through learning, the use of professional knowledge of stakeholders and the form of project knowledge can substantially increase the management power of the public sector. Case IV had an overall better performance, as the public sector, first, was equipped with a better sense of governing, which lead to better control over the process and the form and use of knowledge. As a result, the public sector gained more experience and improved their capability in governing similar infrastructure projects with increased power. 


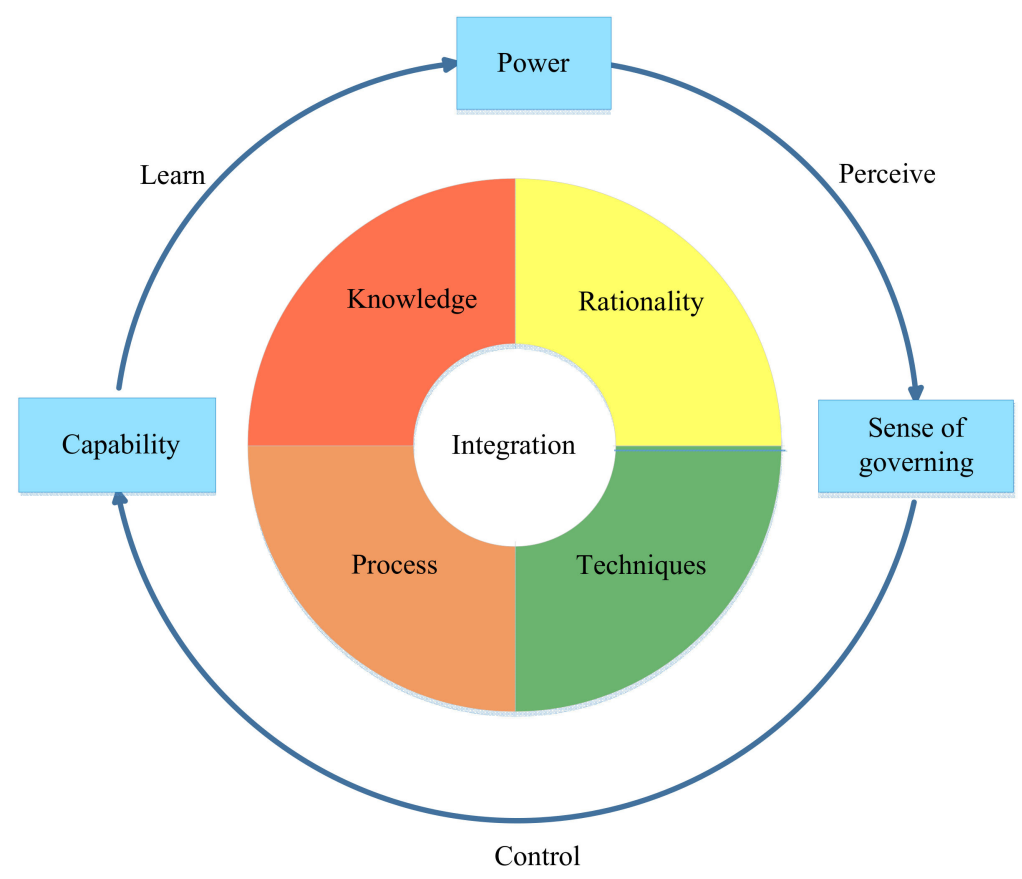

Figure 3. The governance role of the public sector in a PPP project.

The indicators identified for the four dimensions further explain the integrated management process of the public sector in PPP projects, and therefore are suitable to use to evaluate the management efficiency of the public sector. During the interview, experts reviewed their role in the management of case projects and discovered the ignorance of some of the indicators, as they were "not aware of the significance of such management activities to the success of the PPP project." In traditional infrastructure projects, the public sector only needs to focus on part of the core dimensions and does not involve the whole lifecycle of the project under such a long-term contract to a single private sector. An expert claimed that the management team "did not pay much attention to the cross-disciplinary cooperation between professionals during the design stage", as they "did not realize its relationship with the whole lifecycle design optimization". These types of evidence also showed that the public sector has not fully accepted the indicators as an integrated system.

The integration of the four dimensions constitutes the way the public sector governs a PPP project, as many of the indicators share mutual benefits, such as R1 with R4 and T5 with K3. The complexity of the management activities for the public sector, as illustrated in the model, indicates that the public sector must be equipped with cross disciplinary knowledge and comprehensive decision-making abilities. The standardized and appropriate guidance from the central government is, hence, necessary to ensure an excellent management efficiency of the local governments. Given the unique arrangement of PPP and the special relationships between the public and private sectors, it should be the central government's responsibility to instill the mentality of governing to the local governments and provide adequate support and instruments for them to control and to learn from the project efficiently.

The evaluation results of the case studies stressed the need to instruct the public sector on some critical indicators. The public sector held an unadvisable understanding of the roles of some of the indicators, which were either overlooked or underperformed by the public sector in the case projects. The central government, therefore, should further regulate the activities of the public sector and help the local governments gain a full perception of the various important aspects concerning management efficiency and performance of their management duties.

In practice, the central government should perform as supporter, regulator, and supervisor to manage the emerging huge PPP market in China. In particular, the central government should pay greater attention to those indicators that the public sector performed either insufficiently or 
inconsistently, where training, guidance, and instructions are most in need. In order to improve the whole lifecycle management efficiency of the public sector, the central government should consider further standardization of these issues to improve the management capacities and skills of the public sector PPP, instead of giving only principle instructions. The training program for local governments could also help them understand the importance of each of the indicators identified in this research, which covered the compulsory management capacities and key performance indicators for the local governments. A complete performance review of the public sector could increase the accountability of the government [55].

The indicators identified in this research provide a reference for the upper-level supervision governmental departments to deliver a performance review of the public sector in PPP projects, in order to help them understand the focuses and priorities of their management responsibilities and achieve sustainable objectives, such as minimum whole life costs, optimized whole life design, reduced environmental impacts, and energy efficiency.

The introduction of standardized quantitative calculation or measurement tools for the public sector could potentially reduce the inconsistency between the approaches of different local governments and improve the efficient and accuracy of their approaches. The introduction of an education program, assessment, and approval standards for PPP-related consultancy service providers is also an effective way to ensure the quality control of consultancy. The government can also encourage the private consultancy and the local government to form a long-term collaboration, which could benefit the continuality of projects and better implement the integrated whole lifecycle management. As the PPP market in China adopts a centralized approach (all PPP projects have to be initiated and approved by the central government), the strategies suggested above would potentially receive maximum effects in improving the management efficiency of the public sector in PPP projects.

\section{Conclusions}

This study discussed the whole lifecycle management efficiency of the public sector in PPP infrastructure projects, through a governmentality lens. The analytical framework, consisting of four dimensions, i.e., rationality, techniques, process, and knowledge, and 29 indicators, was developed to assist in the evaluation of the management efficiency of the local governments in PPP projects. The practical implementations of the framework are two-fold. First, it can be used as a performance evaluation tool for the central government to review the management efficiency of the public sector in PPP projects and target the loopholes in PPP implementation. Secondly, the local government can adopt the framework as a self-assessment tool to ensure their efficient governing of PPP project during its whole lifecycle.

Purposely designed multiple case studies were carried out to examine the whole lifecycle management efficiency of the public sector in urban infrastructure projects in China. The results revealed the challenges that the public sector faces in managing the whole lifecycle of an infrastructure project, which can affect the achievement of sustainability. The public sectors showed relatively high management efficiency of the public sector in rationality and techniques, and low efficiency in knowledge and process. The findings revealed inadequate performance of the public sector on some indicators and inconsistent approaches of the public sector on some others. Then, the potential factors that affected the management efficiency of the public sector were discussed, which included the lack of detailed instructions and standard quantitative measurement methods, and quality of consultancy.

On the basis of the case studies, some suggestions were provided to the central government for improving the management efficiency of the public sector, to further regulate the PPP market and address the loopholes as follows: (1) introduce training, guidance, and instruction; (2) further regulate the activities of the public sector; (3) complete performance reviews; (4) standardize quantitative calculation or measurement tools; (4) education programs, assessments, and approval standards for PPP-related consultancy service providers; and (5) encourage the private consultancy and the local government to form a long-term collaboration. 
In light of the findings, a conceptual model was developed to demonstrate the governance role of the public sector in a PPP project and the way for the public sector to promote sustainable PPP. The research contributes to the PPP literature by investigating the governance role and assessment tool for the public sector in whole lifecycle management of PPP infrastructure projects. The results can benefit the decision makers and local governments involved in the PPP market to deliver sustainability-oriented and integrated whole lifecycle management of PPP.

The exploratory study did not aim to discuss the relationships between the various indicators, nor to establish a weighted evaluation system to quantify the management efficiency of the public sector in the PPP projects. Future studies are recommended to explore the internal relationship between the indicators and their importance differences to measure management efficiency of the public sector. The case projects were limited to infrastructure projects in China, while researchers could test the framework and models by using other types of projects from different countries for comparison studies. This would also provide valuable findings and knowledge to the academic researchers and government decision makers concerning PPP procurement.

Author Contributions: Research idea, guidance of research team, writing manuscript, N.W.; data collection, analysis, M.M.; comparison analysis, interview survey, Y.L.All authors have read and agreed to the published version of the manuscript.

Funding: This research is funded by the National Social Science Foundation, China, (grant no. 19VHQ009).

Conflicts of Interest: The authors declare no conflict of interest.

\section{References}

1. Treasury, H.M. Public Private Partnerships: The Government's Approach; Stationery Office: London, UK, 2000.

2. Wang, N.; Chen, X.; Wu, G. Public private partnerships, a value for money solution for clean coal district heating operations. Sustainability 2019, 11, 2386. [CrossRef]

3. Liu, J.; Love, P.E.D.; Davis, P.R.; Smith, J.; Regan, M. Conceptual Framework for the Performance Measurement of Public-Private Partnerships. J. Infrastruct. Syst. 2015, 21, 04014023. [CrossRef]

4. Wang, N.; Chang, Y.; El-Sheikh, A.A. Monte Carlo simulation approach to life cycle cost management. Struct. Infrastruct. Eng. 2012, 8, 739-746. [CrossRef]

5. Cui, C.; Liu, Y.; Hope, A.; Wang, J. Review of studies on the public private partnerships (PPP) for infrastructure projects. Int. J. Proj. Manag. 2018, 36, 773-794. [CrossRef]

6. Wilson, D.I.; Pelham, N.; Duffield, C.F. A review of Australian PPP governance structures. J. Financ. Manag. Prop. Constr. 2010, 15, 198-215. [CrossRef]

7. Abu Rashed, M.; Alam, M.M.; Ibrahim, Y. Central Public-Private Partnership (PPP) development facility for enhancing government obligation and efficiency in PPP project. Int. J. Inform. Technol. Proj. Manag. 2017, 8, 66-77. [CrossRef]

8. Chen, C.; Li, D.; Man, C.X. Toward sustainable development? A bibliometric analysis of PPP-related policies in China between 1980 and 2017. Sustainability 2019, 11, 142. [CrossRef]

9. Zhang, X. Factor analysis of public clients' best-value objective in public-privately partnered infrastructure projects. J. Constr. Eng. Manag. 2006, 132, 956-965. [CrossRef]

10. Wang, N.; Wei, K.; Sun, H. Whole life project management approach to sustainability. J. Manag. Eng. 2014, 30, 246-255. [CrossRef]

11. Li, Y.; Song, H.; Sang, P.; Chen, P.; Liu, X. Review of Critical Success Factors (CSFs) for green building projects. Build. Environ. 2019, 158, 182-191. [CrossRef]

12. Rose, N.; Miller, P. Political-power beyond the state-Problematics of government. Brit. J. Sociol. 1992, 43, 173-205. [CrossRef]

13. Foucault, M.; Burchell, G.; Gordon, C.; Miller, P. The Foucault Effect: Studies in Governmentality; University of Chicago Press: Chicago, IL, USA, 1991; pp. 87-104.

14. Barthes, R. Mythologies; Hill and Wang: New York, NY, USA, 2013.

15. Macquarie University. The Macquarie Dictionary; Revised Editioned; Macquarie University: Sydney, Australia, 1985. 
16. Wibowo, A.; Alfen, H.W. Government-led critical success factors in PPP infrastructure development. Built Environ. Proj. Asset Manag. 2015, 5, 121-134. [CrossRef]

17. Liu, J.; Love, P.E.D.; Carey, B.; Smith, J.; Regan, M. Ex-ante evaluation of public-private partnerships: Macroeconomic analysis. J. Infrastruct. Syst. 2015, 21, 04014038. [CrossRef]

18. Boynton, A.C.; Zmud, R.W. An assessment of critical success factors. Sloan Manag. Rev. 1984, 25, 17-27.

19. Tang, L.; Shen, Q.; Skitmore, M.; Cheng, E.W.L. Ranked critical factors in PPP briefings. J. Manag. Eng. 2013, 29, 164-171. [CrossRef]

20. Ng, S.T.; Wong, Y.M.W.; Wong, J.M.W. Factors influencing the success of PPP at feasibility stage-A tripartite comparison study in Hong Kong. Habitat Int. 2012, 36, 423-432. [CrossRef]

21. Raisbeck, P.; Tang, L. Identifying design development factors in Australian PPP projects using an AHP framework. Constr. Manag. Econ. 2013, 31, 20-39. [CrossRef]

22. Hueskes, M.; Koppenjan, J.; Verweij, S. Public-private partnerships for infrastructure: Lessons learned from Dutch and Flemish PhD-theses. Eur. J. Transp. Infrastruct. Res. 2019, 19, 160-176.

23. Li, B.; Akintoye, A.; Edwards, P.; Hardcastle, C. Critical success factors for PPP/PFI projects in the UK construction industry. Constr. Manag. Econ. 2005, 23, 459-471. [CrossRef]

24. Mladenovic, G.; Vajdic, N.; Wundsch, B.; Temeljotov-Salaj, A. Use of key performance indicators for PPP transport projects to meet stakeholders' performance objectives. Built Environ. Proj. Asset Manag. 2013, 3, 228-249. [CrossRef]

25. Yuan, J.; Zeng, A.; Skibniewski, M.; Li, Q. Selection of performance objectives and key performance indicators in public-private partnership projects to achieve value for money. Constr. Manag. Econ. 2009, 27, 253-270. [CrossRef]

26. Gazley, B. Linking collaborative capacity to performance measurement in government-Nonprofit partnerships. Nonprof. Volunt. Sec. Q. 2010, 39, 653-673. [CrossRef]

27. Mahoney, J.T.; McGahan, A.M.; Pitelis, C.N. The interdependence of private and public interests. Organ. Sci. 2009, 20, 1034-1052. [CrossRef]

28. Hsueh, C.; Chang, L. Critical success factors for PPP infrastructure: Perspective from Taiwan. J. Chin. Inst. Eng. 2017, 40, 370-377. [CrossRef]

29. Chou, J.; Pramudawardhani, D. Cross-country comparisons of key drivers, critical success factors and risk allocation for public-private partnership projects. Int. J. Proj. Manag. 2015, 33, 1136-1150. [CrossRef]

30. Abdul-Aziz, A.R.; Kassim, P.S.J. Objectives, success and failure factors of housing public-private partnerships in Malaysia. Habitat Int. 2011, 35, 150-157. [CrossRef]

31. Cheung, S.; Tam, C.; Ndekugri, I.; Harris, F. Factors affecting clients' project dispute resolution satisfaction in Hong Kong. Constr. Manag. Econ. 2000, 18, 281-294. [CrossRef]

32. Al-Tmeemy, S.M.H.M.; Abdul-Rahman, H.; Harun, Z. Future criteria for success of building projects in Malaysia. Int. J. Proj. Manag. 2011, 29, 337-348. [CrossRef]

33. Robinson, H.; Scott, J. Service delivery and performance monitoring in PFI/PPP projects. Constr. Manag. Econ. 2009, 27, 181-197. [CrossRef]

34. Oyedele, L.O. Avoiding performance failure payment deductions in PFI/PPP projects: Model of critical success factors. J. Perform. Constr. Facil. 2013, 27, 283-294. [CrossRef]

35. Liyanage, C.; Villalba-Romero, F. Measuring success of PPP transport projects: A cross-case analysis of toll roads. Transp. Rev. 2015, 35, 140-161. [CrossRef]

36. Foucault, M. Power/Knowledge: Selected Interviews and Other Writings 1972-1977; Pantheon Books: New York, NY, USA, 1980.

37. Foucault, M. The subject and power. Crit. Inq. 1982, 8, 777-795. [CrossRef]

38. Valladares, C.; Boelens, R. Mining for mother earth. Governmentalities, sacred waters and nature's rights in Ecuador. Geoforum 2019, 100, 68-79. [CrossRef]

39. Townley, B. Foucault, power knowledge, and its relevance for human-resource management. Acad. Manag. Rev. 1993, 18, 518-545. [CrossRef]

40. Abdullah, A.; Khadaroo, I. The governmentality and accountability of UK national museums and art galleries. Account. Forum 2017, 41, 266-276. [CrossRef]

41. Marques, R.C. Why not regulate PPPs? Util. Policy 2017, 48, 141-146. [CrossRef]

42. Dean, M. Governmentality: Power and Rule in Modern Society, 2nd ed.; SAGE Publications Ltd: London, UK, 2012. 
43. Bevir, M. Governance and governmentality after neoliberalism. Policy Polit. 2011, 39, 457-471. [CrossRef]

44. Foss, N.J.; Husted, K.; Michailova, S. Governing knowledge sharing in organizations: Levels of analysis, governance mechanisms, and research directions. J. Manag. Stud. 2010, 47, 455-482. [CrossRef]

45. Müller, R.; Pemsel, S.; Shao, J. Organizational enablers for project governance and governmentality in project-based organizations. Int. J. Proj. Manag. 2015, 33, 839-851. [CrossRef]

46. Ninan, J.; Clegg, S.; Mahalingam, A. Branding and governmentality for infrastructure megaprojects: The role of social media. Int. J. Proj. Manag. 2019, 37, 59-72. [CrossRef]

47. Fraser, A.; Baeza, J.; Boaz, A.; Ferlie, E. Biopolitics, space and hospital reconfiguration. Soc. Sci. Med. 2019, 230, 111-121. [CrossRef] [PubMed]

48. Flores, N. Creating republican machines: Language governmentality in the United States. Linguist. Educ. 2014, 25, 1-11. [CrossRef]

49. Thompson, L. The role of nursing in governmentality, biopower and population health: Family health nursing. Health Place 2008, 14, 76-84. [CrossRef] [PubMed]

50. O'Keeffe, P. Creating a governable reality: Analysing the use of quantification in shaping Australian wheat marketing policy. Agric. Hum. Values 2018, 35, 553-567. [CrossRef]

51. Muller, R.; Zhai, L.; Wang, A. Governance and governmentality in projects: Profiles and relationships with success. Int. J. Proj. Manag. 2017, 35, 378-392. [CrossRef]

52. Darling, J. Domopolitics, governmentality and the regulation of asylum accommodation. Polit. Geogr. 2011, 30, 263-271. [CrossRef]

53. Patil, N.A.; Laishram, B.S. Sustainability of Indian PPP procurement process Development of strategies for enhancement. Built Environ. Proj. Asset Manag. 2016, 6, 491-507. [CrossRef]

54. Atmo, G.; Duffield, C. Improving investment sustainability for PPP power projects in emerging economies: Value for money framework. Built Environ. Proj. Asset Manag. 2014, 4, 335-351. [CrossRef]

55. Ke, Y.; Hao, W.; Ding, H.; Wang, Y. Factors influencing the private involvement in urban rail public-private partnership projects in China. Constr. Econ. Build. 2017, 17, 90-106. [CrossRef]

56. Xiong, W.; Yuan, J.; Li, Q.; Skibniewski, M.J. Performance objective-based dynamic adjustment model to balance the stakeholders' satisfaction in PPP projects. J. Civ. Eng. Manag. 2015, 21, 539-547. [CrossRef]

57. Dixon, T.; Pottinger, G.; Jordan, A. Lessons from the private finance initiative in the UK. J. Prop. Invest. Financ. 2005, 23, 412-423. [CrossRef]

58. Lam, P.T.I.; Javed, A.A. Comparative study on the use of output specifications for Australian and UK PPP/PFI projects. J. Perform. Constr. Facil. 2015, 29, 04014061. [CrossRef]

59. Khosravi, S.; Afshari, H. A success measurement model for construction projects. In International Proceedings of Economics Development and Research; Dan, C., Ed.; Int Assoc Computer Science \& Information Technology Press-Iacsit Press: Singapore, 2011; Volume 11, pp. 186-190.

60. Zhang, X.Q. Public clients' best value perspectives of public private partnerships in infrastructure development. J. Constr. Eng. Manag. 2006, 132, 107-114. [CrossRef]

61. Mudyarabikwa, O.; Regmi, K. Public-private partnerships and efficiency in public procurement of primary healthcare infrastructure: A qualitative research in the NHS UK. J. Publ. Health 2016, 24, 91-100. [CrossRef]

62. Osei-Kyei, R.; Chan, A.P.C. Implementing public-private partnership (PPP) policy for public construction projects in Ghana: Critical success factors and policy implications. Int. J. Constr. Manag. 2017, 17, 113-123. [CrossRef]

63. Owolabi, H.A.; Oyedele, L.O.; Alaka, H.A.; Ajayi, S.O.; Akinade, O.O.; Bilal, M. Critical success factors for ensuring bankable completion risk in PFI/PPP megaprojects. J. Manag. Eng. 2020, 36, 04019032. [CrossRef]

64. Eisenhardt, K.M. Building theories from case-study research. Acad. Manag. Rev. 1989, 14, 532-550. [CrossRef]

65. Ferlie, E.; Fitzgerald, L.; Wood, M.; Hawkins, C. The nonspread of innovations: The mediating role of professionals. Acad. Manag. J. 2005, 48, 117-134. [CrossRef]

66. Deacon, D.; Bryman, A.; Fenton, N. Collision or collusion? A discussion and case study of the unplanned triangulation of quantitative and qualitative research methods. Int. J. Soc. Res. Method. 1998, 1, 47-63. [CrossRef]

(C) 2020 by the authors. Licensee MDPI, Basel, Switzerland. This article is an open access article distributed under the terms and conditions of the Creative Commons Attribution (CC BY) license (http://creativecommons.org/licenses/by/4.0/). 